\title{
Isolation of Streptococcus agalactiae and an aquatic birnavirus from doctor fish Garra rufa L
}

\author{
Neil M Ruane*, Evelyn M Collins, Michelle Geary, David Swords, Cathy Hickey and Fiona Geoghegan
}

\begin{abstract}
Background: The doctor fish, Garra rufa, has become increasingly popular as a treatment for skin disorders and for pedicures in recent years. Despite this there is very little information available regarding the welfare of these fish and the range of potential pathogens they may carry. In this study, a group of fish suffering from post-transport mortalities were examined and the isolated pathogens identified.

Findings: Group B Streptococcus agalactiae was isolated from kidney swabs of the fish and found to be resistant to a number of antibiotics. In addition to this, a fish virus belonging to the aquabirnavirus group, serogroup C was isolated for the first time in Ireland. However, no clinical signs of disease typical of bacterial or viral infections were observed in any fish examined.

Conclusions: As no clinical signs of disease attributable to either of the pathogens identified were found it was concluded that the mortalities were most likely due to transport related stress exacerbated by the presence of the pathogens. Further work is required to assess the suitability of current transport strategies and to examine the potential risk associated with the transport of live ornamental fish.
\end{abstract}

Keywords: Aquabirnavirus, Streptococcus agalactiae, Garra rufa

\section{Background}

Garra rufa (Heckel, 1843), commonly known as doctor fish, is a non-migratory, freshwater species belonging to the carp family (Cyprinidae). The native range of G. rufa is from the Persian Gulf to the eastern Mediterranean, encompassing all the major river basins in that region [1]. Doctor fish are benthic feeders, known to adhere by suction to rocks while feeding on plant material using a modified lower lip termed 'mental adhesive disc' [2]. It is this feeding behaviour which led to the use of these fish as treatments for skin disorders such as psoriasis for many years, most notably in Turkey where the practice was first described in 1989 [3]. Although the exact mechanisms are not known, there is some scientific evidence which suggests that the use of these fish may be beneficial for people with skin problems $[4,5]$. In recent years, this has been capitalised on by the health spa industry with a proliferation of 'foot spas' offering treatments using doctor fish which in turn has placed a high demand for their supply. Transport of ornamental

\footnotetext{
* Correspondence: Neil.Ruane@marine.ie

Fish Health Unit, Marine Institute, Rinville, Oranmore, Co. Galway, Ireland
}

fish is characterised by high loading densities, high levels of metabolic waste in the transport water and post-transport mortality due to the stressful nature of the procedure [6]. In addition to this, the movement of live fish is often one of the main risk factors associated with the spread of any disease [7]. To date, there are very few reports describing pathogens or disease in $G$. rufa and such information is needed for the effective analysis of any risk associated with the transport of large numbers of these fish. This report describes the isolation of the bacteria Streptococcus agalactiae and an aquatic birnavirus from G. rufa submitted to the laboratory by a health spa when high levels of mortality were noted after delivery.

\section{Methods}

In August 2011, a health spa reported a number of fish dead on arrival after receiving a batch of G. rufa and that mortalities continued to occur over the following days after placing the fish in a holding tank. Thirty of these fish were brought to the Fish Health Unit laboratory, Marine Institute, Galway and samples were taken for routine bacteriological, virological and histological 
examination. Initial examination showed that the fish were lethargic and no external parasites were observed following skin and gill scrapes. Kidney swabs from five separate fish were plated onto tryptone soya agar (TSA) and Colombia blood agar (CBA) plates and incubated at 22,30 and $37^{\circ} \mathrm{C}$. Growth of bacterial colonies was identified on the basis of standard phenotypic testing criteria (Gram stain, motility, oxidase activity). Sequencing of the partial $16 \mathrm{~S}$ ribosomal RNA gene was also used to confirm the identity of the bacteria [8] and serotyping was carried out using a commercial kit (Oxoid). Sensitivity of the bacteria to a range of antibiotics was also performed. For virus isolation, fifteen fish (three pools of five) were homogenised and inoculated onto bluegill Lepomis macrochirus fry (BF-2) and epithelioma papulosum cyprinid (EPC) cell lines and incubated at $20^{\circ} \mathrm{C}$. When cytopathic effect was noted on the cell lines, the virus was identified using commercial ELISA and IFAT kits (TestLine and BioX Diagnostics) and by nested RT-PCR [9]. For histology, ten whole fish were fixed in neutral-buffered formalin and processed according to standard methods. Sections were cut at $5 \mu \mathrm{m}$ and stained with haematoxylin-eosin.

PCR products were visualised after electrophoresis on a $1.5 \%(\mathrm{w} / \mathrm{v})$ agarose gel in TAE buffer (40 mM Tris, $20 \mathrm{mM}$ acetic acid, $2 \mathrm{mM}$ ethylenediaminetetraacetic acid) stained with ethidium bromide, with the Quantity One 1-D Analysis System software on a UV Transluminator (Bio-Rad). The PCR products were purified and sequenced commercially (Sequiserve). The virus isolate identified in this study was given the reference IRLF73-11 and compared with nine other birnavirus isolates (Figure 1). These included a known infectious pancreatic necrosis virus isolate (IRL-F56-11) isolated from a marine Atlantic salmon farm, representatives of IPNV serogroups
A1, A2 and A3 and five isolates representing serogroups C and D [8]. Multiple sequence alignments were performed by Clustal W analysis and all phylogenetic analyses were conducted using MEGA 5 [10].

\section{Results}

The characteristics of the bacteria isolated are listed in Table 1. The consensus sequence for the partial $16 \mathrm{~S}$ ribosomal RNA gene was subjected to a BLAST search (http://blast.ncbi.nlm.nih.gov/Blast.cgi) and was found to have $100 \%$ homology with Streptococcus agalactiae. Serotyping further confirmed that it was a Group B Streptococcus. Optimal growth was observed at $30^{\circ} \mathrm{C}$, with slow growth at $22^{\circ} \mathrm{C}$ and no growth at $37^{\circ} \mathrm{C}$. Of the six antibiotics used for the sensitivity testing, no zones of inhibition were recorded for flumequine, oxolinic acid, sarafloxacin and trimethoprim/sulphamethoxazole suggesting that the bacteria were resistant to these antibiotics. Some sensitivity to amoxicillin and oxytetracycline was noted with zones of 5 and $10 \mathrm{~mm}$ diameters recorded respectively.

Cytopathic effects were noted on the BF2 cell lines following the first passage after seven days, however the EPC cell line was unaffected. Tests using commercial ELISA and IFAT kits for viral haemorrhagic septicaemia (VHS), infectious pancreatic necrosis (IPN), infectious haematopoietic necrosis (IHN) and spring viraemia of carp (SVC) viruses yielded negative results. Phylogenetic analysis of the partial sequence of the viral protein 1 (VP1) gene showed that the virus was closely related to serogroup $C$ and D aquabirnaviruses (Figure 1). The analysis also showed that the G. rufa birnavirus was assigned to the clade including blotched snakehead virus (BSNV), the type species for Blosnavirus. All selected isolates of serogroup $\mathrm{A}$, which have IPNV as the type

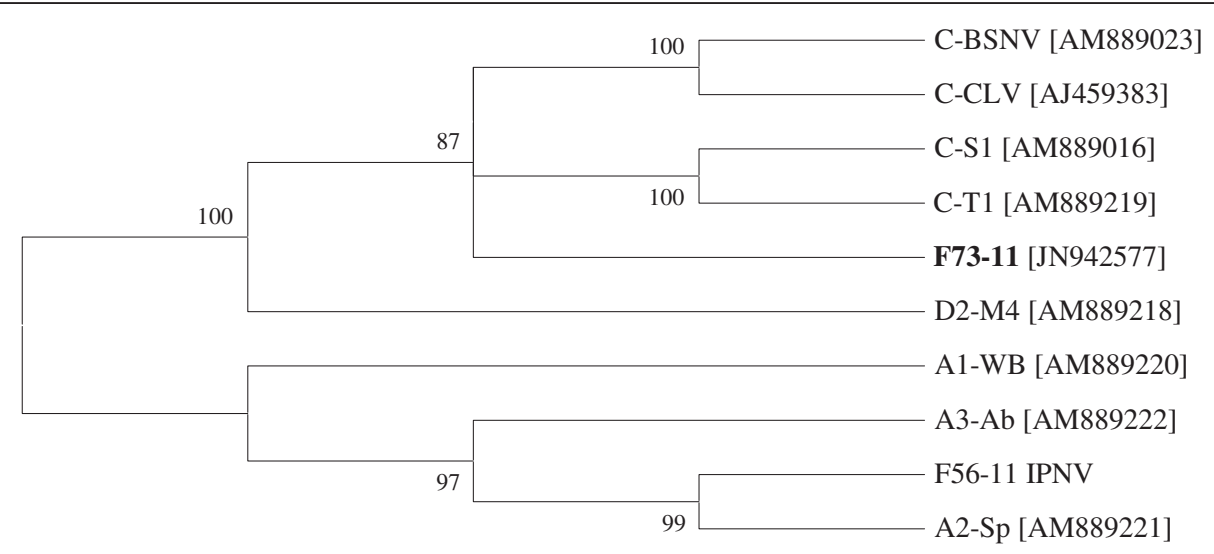

Figure 1 A condensed phylogenetic tree showing relationships between the Garra rufa birnavirus F73-11 and other aquatic birnaviruses from serogroups A, C and D (indicated as a prefix), based on nucleotide sequence comparisons of a 226 bp segment of the VP1 protein. The tree was constructed using the neighbour-joining method and 1000 bootstrap replicates were performed for each analysis to assess the likelihood of the tree construction. Only values $>70$ are indicated. [GenBank accession numbers are shown in brackets]. 


\begin{tabular}{ll} 
Table $\mathbf{1}$ Characteristics of the bacteria isolated from \\
Garra rufa and identified as Streptococcus agalactiae \\
\hline Characteristic \\
\hline Gram stain & Positive bacilli \\
Morphology & Small white circular colonies \\
Motility & Negative \\
O/F & Inert \\
Oxidase & Negative \\
Haemolysis & $\beta$ \\
Growth at $22^{\circ} \mathrm{C}$ & Yes (slow) \\
Growth at $30^{\circ} \mathrm{C}$ & Yes \\
Growth at $37^{\circ} \mathrm{C}$ & No \\
Amoxycillin $(10 \mu \mathrm{g})$ & Sensitive \\
Flumequine $(4 \mu \mathrm{g})$ & Resistant \\
Oxolinic acid $(2 \mu \mathrm{g})$ & Resistant \\
Oxytetracycline $(30 \mu \mathrm{g})$ & Sensitive \\
Sarafloxacin $(5 \mu \mathrm{g})$ & Resistant \\
Trimethoprim/Sulphamethoxazole $(25 \mu \mathrm{g})$ & Resistant \\
\hline
\end{tabular}

species, grouped together in one clade, although the assay was able to differentiate each of the serotypes (A1-A3) and grouped the isolate, IRL-F56-11, together with serotype A2.

After histological examination of the internal organs, no pathology associated with bacterial or viral infection was observed.

\section{Discussion}

This study reports the first isolation of Streptococcus agalactiae and an aquatic birnavirus from the doctor fish, G. rufa in Ireland. As the fish examined in this study did not show clinical signs of disease, the cause of the mortality was most likely due to transport stress exacerbated by the presence of both pathogens. However it should be noted that acute mortalities can often occur following viral/bacterial infections with little or no clinical signs of disease. The increased popularity of health spas using these fish for pedicures has resulted in a dramatic rise in the demand for their supply. A 2012 report from the UK [11] stated that between 15,000-20,000 G. rufa were imported each week through Heathrow Airport, the main border inspection post for the import of live fish into the UK. Despite the large numbers of fish coming into the EU, there is very little published information available on the requirements of these fish, either in terms of fish welfare (transport, husbandry etc.), or in terms of the risk they pose to native fish stocks and to customers who use these fish at health spas. Mortality of G. rufa in fish hatcheries has been associated with the aquatic pathogens Aeromonas sobria [12] and Citrobacter freundii [13]. This study reported the isolation of $S$. agalactiae from moribund fish without clinical signs of disease, although it is known that this bacteria may be pathogenic for fish species including G. rufa $[11,14]$. These bacteria, also known as Lancefield group B streptococcus, have a broad host range and can cause meningoencephalitis in fish, mastitis in cattle and meningitis in human neonates. Although there is a high genetic diversity between strains of S. agalactiae, experimental transmission studies have shown that isolates from human, bovine and piscine origins can cause clinical disease in fish $[15,16]$. A range of other bacteria with the potential to cause zoonotic infections have been isolated from doctor fish [11] including vibrio and mycobacteria species. As these bacteria do not have optimal growth at $37^{\circ} \mathrm{C}$, infections are mostly confined to the superficial, cooler body tissues of the extremities. Reports of infections are rare however and have mostly been confined to fish handlers and aquarium hobbyists [17], however at least one infection due to a pedicure treatment has been reported [18]. The UK Health Protection Agency has published guidelines for the management of health risks associated with fish pedicures and has classified the risk of zoonotic infection as low [19]. The G. rufa isolate was also found to be resistant to four out of six antibiotics tested and the susceptibility to the remaining two antibiotics is questionable due to the small size of the inhibition zones and the general lack of data in which to calculate epidemiological cut-off values for determining sensitivity. Antimicrobial resistance of bacteria isolated from tropical fish is well known due to the widespread use of antibiotics in the transport water $[11,20]$.

The birnavirus family are double-stranded, non-enveloped RNA viruses consisting of four genera, two of which contain aquatic viruses, Aquabirnavirus (type species: infectious pancreatic necrosis virus IPNV) and Blosnavirus (type species: blotched snakehead virus BSNV). Aquabirnaviruses have been isolated from aquatic animals throughout the world and infectious pancreatic necrosis is a significant disease of farmed salmonids in Ireland [21]. Although this is the first isolation in Ireland of an aquatic birnavirus, other than IPNV, mortalities due to birnavirus infections in tropical fish have been reported previously $[10,22]$. Sequence analysis indicated that the isolate was similar to other viruses, such as BSNV, isolated from tropical fish [9] and initially assigned to a separate serogroup (C) within the genus Aquabirnavirus. Studies on BSNV [23] showed that it was distinct from other aquabirnaviruses and was assigned to its own genus, Blosnavirus [24]. Although further characterisation of the virus isolate from this study is required, the results would suggest that the birnavirus isolated from G. rufa is more related to blosnavirus than aquabirnavirus. 


\section{Conclusion}

The transport of live aquatic animals is a significant risk factor in the spread of disease [7]. The ornamental fish industry is an expanding sector with large volumes of fish traded annually [25]. It is a concern for a trading block such as the European Union, that imported animals and animals traded within the Community could potentially pose a human health risk. Council Directive 2006/88/EC, which currently regulates the movements of live fish into and within Europe, focuses on the control of diseases of fish health significance rather than of public health significance. In fact, it has been suggested that ornamental fish represent a special case in live animal trade due to the large number of fish species originating from numerous sources, together with a lack of knowledge of the potential pathogens which they may carry [25]. This is supported by the detection of the pathogens described in this study, in sub-clinically infected fish, highlighting the risk of transmission to other aquarium fish and a need for the establishment of improved quarantine and pathogen screening procedures for fish such as G. rufa which are to be used in the health sector.

\section{Competing interests}

The authors declare that they have no competing interests.

\section{Authors' contributions}

NR carried out the molecular analysis, sequence alignment and drafted the manuscript. EC performed the histopathology analysis and helped to draft the manuscript. MG performed the bacteriology analysis. DS performed the virological analysis. CH performed the histological analysis. FG helped to draft the manuscript and gave final approval of the version to be published. All authors read and approved the final manuscript.

Received: 1 May 2013 Accepted: 10 September 2013

Published: 13 September 2013

\section{References}

1. Jarvis PL: Biological synopsis of Garra rufa. Can MS Rpt Fish Aquat Sci 2011, 2946:vi + 14p.

2. Zhang E: Phylogenetic relationships of labeonine cyprinids of the disc-bearing group (Pisces: Teleostei). Zool Stud 2005, 44:130-143.

3. Warwick D, Warwick J: The doctor fish-a cure for psoriasis? Lancet 1989, 335:1093-1094.

4. Ozçelik S, Polat HH, Akyol M, Yalçin AN, Ozçelik D, Marufihah M: Kangal hot spring with fish and psoriasis treatment. J Dermatol 2000, 27:386-390.

5. Grassberger M, Hoch W: Ichthyotherapy as alternative treatment for patients with psoriasis: a pilot study. Evid Based Complement Alternat Med 2006, 3:483-488.

6. Lim LC, Dhert P, Sorgeloos P: Recent developments and improvements in ornamental fish packaging systems for air transport. Aquacult Res 2003, 34:923-935.

7. Rodgers CJ, Mohan CV, Peeler EJ: The spread of pathogens through trade in aquatic animals and their products. Rev Sci Tech Off Int Epiz 2011, 30:241-256

8. Lane DJ, Pace B, Olsen GJ, Stahl DA, Sogin ML, Pace NR: Rapid determination of $16 \mathrm{~S}$ ribosomal RNA sequences for phylogenetic analyses. Proc Natl Acad Sci U S A 1985, 82:6955-6959.

9. Dixon PF, Ngoh GH, Stone DM, Chang SF, Way K, Kueh SLF: Proposal for a fourth aquabirnavirus serogroup. Arch Virol 2008, 153:1937-1941.

10. Tamura K, Peterson D, Peterson N, Stecher G, Nei M, Kumar S: MEGA5: Molecular evolutionary genetics analysis using maximum likelihood, evolutionary distance, and maximum parsimony methods. Mol Biol Evol 2011, 28:2731-2739.
11. Verner-Jeffreys DW, Baker-Austin C, Pond MJ, Rimmer GSE, Kerr R, Stone D, Griffin R, White P, Stinton N, Denham K, Leigh J, Jones N, Longshaw M, Feist SW: Zoonotic disease pathogens in fish used for pedicure. Emerg Infect Dis 2012, 18:1006-1008.

12. Majtán J, Černy J, Ofúkaná A, Takáč P, Kozánek M: Mortality of therapeutic fish Garra rufa caused by Aeromonas sobria. Asian Pac J Trop Biomed 2012, 2:85-87.

13. Baeck GW, Kim JH, Choresca C Jr, Gomez DK, Shin SP, Han JE, Park SC: Mass mortality of doctor fish (Garra rufa obtusa) caused by Citrobacter freundii infection. J Vet Clinics 2009, 26:150-154.

14. Evans JJ, Klesius PH, Gilbert PM, Shoemaker CA, Al Sarawi MA, Landsberg J, Duremdez R, Al Marzouk A, Al Zenki S: Characterization of $\beta$-haemolytic Group B Streptococcus agalactiae in cultured seabream, Sparus auratus L., and wild mullet, Liza klunzingeri (Day), in Kuwait. J Fish Dis 2002, 25:505-513.

15. Evans JJ, Bohnsack JF, Klesius PH, Whiting AA, Garcia JC, Shoemaker CA, Takahashi S: Phylogenetic relationships among Streptococcus agalactiae isolated from piscine, dolphin, bovine, and human sources: a dolphin and piscine lineage associated with a fish epidemic in Kuwait is also associated with human neonatal infections in Japan. $J$ Med Microbiol 2008, 57:1369-1376.

16. Pereira UP, Mian GF, Oliveira IC, Benchetrit LC, Costa GM, Figueiredo HC: Genotyping of Streptococcus agalactiae strains isolated from fish, human and cattle and their virulence potential in Nile tilapia. Vet Microbiol 2010, 140:186-192.

17. Decostere A, Hermans K, Haesebrouk F: Piscine mycobacteriosis: a literature review covering the agent and the disease it causes in fish and humans. Vet Microbiol 2004, 99:159-166.

18. An TR, Kai JNS, Adrian M: Cellulitis after treatment in a "fish spa". $10^{\text {th }}$ Congress of the European Federation of Internal Medicine: 5-8 October 2011; Athens; 2011:PP216. www.efim.org.

19. Health Protection Agency: Guidance on the management of the public health risks from fish pedicures; 2011. http://www.hpa.org.uk/webc/HPAwebFile/ HPAweb_C/1317131045549.

20. Verner-Jeffreys DW, Welch TJ, Schwarz T, Pond MJ, Woodward MJ, Haig SJ, Rimmer GSE, Roberts E, Morrison V, Baker-Austin C: High prevalence of multidrug-tolerant bacteria and associated antimicrobial resistance genes isolated from ornamental fish and their carriage water. PLoS One 2009, 4(12):e8388. doi:10.1371/journal.pone.0008388.

21. Ruane NM, McCarthy LJ, Swords D, Henshilwood K: Molecular differentiation of infectious pancreatic necrosis virus isolates from farmed and wild salmonids in Ireland. J Fish Dis 2009, 32:979-987.

22. Shin SP, Gomez DK, Kim JH, Choresca CH Jr, Han JE, Jun JW, Park SC: Detection and genetic analysis of aquabirnaviruses in subclinically infected aquarium fish. J Vet Diag Invest 2011, 23:325-329.

23. Da Costa B, Soignier S, Chevalier C, Henry C, Thory C, Huet JC, Delmas B: Blotched snakehead virus is a new aquatic birnavirus that is slightly more related to avibirnavirus than to aquabirnavirus. J Virol 2003, 77:719-725

24. Carstens $E B$, Ball $L A$ : Ratification vote on taxonomic proposals to the international committee on taxonomy of viruses (2008). Arch Virol 2009, 154:1181-1188.

25. Whittington RJ, Chong R: Global trade in ornamental fish from an Australian perspective: the case for revised import risk analysis and management strategies. Prev Vet Med 2007, 81:92-166.

\section{doi:10.1186/2046-0481-66-16}

Cite this article as: Ruane et al:: Isolation of Streptococcus agalactiae and an aquatic birnavirus from doctor fish Garra rufa L. Irish Veterinary Journal 2013 66:16. 